\title{
Challenges of Designing New Urban Quality in Historical Environment: Based on Final Projects of BA Students of the Department of Urban Design, FA, VGTU
}

\author{
Dalia Dijokienè, Vilnius Gediminas Technical University
}

\begin{abstract}
Historical urban heritage represents not only the accumulation of the wealth of civilization but also a foundation for identity of urban communities. However, a town is still a living system, the existence of which is supported by its constant development, change and growth. Creating a new urban quality in a historical environment without prejudice to the existing harmony is a complex and challenging task. This article looks into and summarizes knowledge accumulated from the final projects of BA students of the Department of Urban Design, Faculty of Architecture, Vilnius Gediminas Technical University (FA, VGTU). It reviews methodology, tasks, solution argumentation and methods of designing new urban quality in a historical environment in BA students' graduation projects.
\end{abstract}

Keywords - Designing new urban quality, historical environment, regeneration of historical parts of a town, urban design, urban open space.

"It is hard to imagine a world without towns. Over millennia towns have been like magnets attracting business, science, culture, politics and innovations. In today's jam-packed, materially advanced world towns are needed for exactly the same reasons" [1]. In the West, towns play a key role in the development of civilization and are among main forces driving cultural developments. Town and its environment are a daily experience of many Europeans. It is difficult to imagine a European town without an old town. The historical centres of most European towns are several centuries or even millennia old. Historical urban heritage represents not only the accumulation of the wealth of civilization but also a foundation for the identity of urban communities. A town is a living system, the existence of which is supported by its constant development, change and growth. Building, demolition and rebuilding have always been taking place in towns. However, today many urban centres are facing the problem of inadequate use of urban space. An increased dependence on the automobile, the attitude of architects of the Modern Movement toward open space, abandonment of industrial, military or transportation sites in the inner core of the town - these are just a few factors that have contributed to the loss of space in our cities [2]. Urban structures with lost spatial quality may be found not only in peripheral parts of towns, but also in historical cores [3].

Qualitative expansion and utilisation of inner territorial resources is highly relevant for every single town. Conversion of the town's historical parts and their revival is a subject that interests not only professional architects and urban designers but also students of architecture. Students often choose derelict territories of the historical part of a town, converted industrial zones or "wilderness" of large-scale construction of residential areas for their term and graduation projects. Being a lecturer at a university and a tutor of graduation projects, the author of this article will review final projects of BA students of the Department of Urban Design, Faculty of Architecture, Vilnius Gediminas Technical University (FA, VGTU). This article focuses on projects drawn up for historical parts of a town. It reviews methodology, tasks, solution argumentation and methods of designing new urban quality in BA students' graduation projects.

\section{Methodology of Graduation Projects of BA Students of the Department of Urban Design, FA, VGTU}

Creating a new urban quality in historical environment without prejudice to the existing harmony is a complex and challenging task. Its solution requires methodological consistency. In order to achieve a good result, the following design stages are in place: the study of features of existing urban structure (analytical part), determination of urban-architectural concept underlying territorial formation (conceptual part), detailed design (project part).

Analytical part. Students start their work by carrying out a detailed and multifaceted analysis of the territory of their choice. They study the historical and urban development of the area and identify what valuable elements of plan and built-up are preserved there. Structural elements that existed in the past are indicated in the plan of the current urban structure. This helps to understand how mature the structure in question is whether its development has been smooth or with deformations. Next, students conduct the urban analysis of the territory's current condition. The following elements are assessed and analysed: the territory's position vis-à-vis the whole town; the network of streets and transport scheme; the natural conditions (landscape, water pools, greenery); predominant built-up morphotypes; elements of the composition of size and space, expressiveness and singleness; architectural quality of the buildings; system of the land lots; visual links between vertical landmarks and public urban spaces; the quality of public and private urban spaces (courts, streets, squares, etc.). This analysis is aimed at assessing the quality of the urban structure in question. The analytical part is summarised in a final plan and supplementing schemes (Figure 1), and the author defines criteria on which he/she bases the concept of a new urban quality in the regenerating territory.

Conceptual part. After studying the urban and architectural heritage, students propose several conceptual solutions for regenerating the blocks. Solutions are presented by means of 

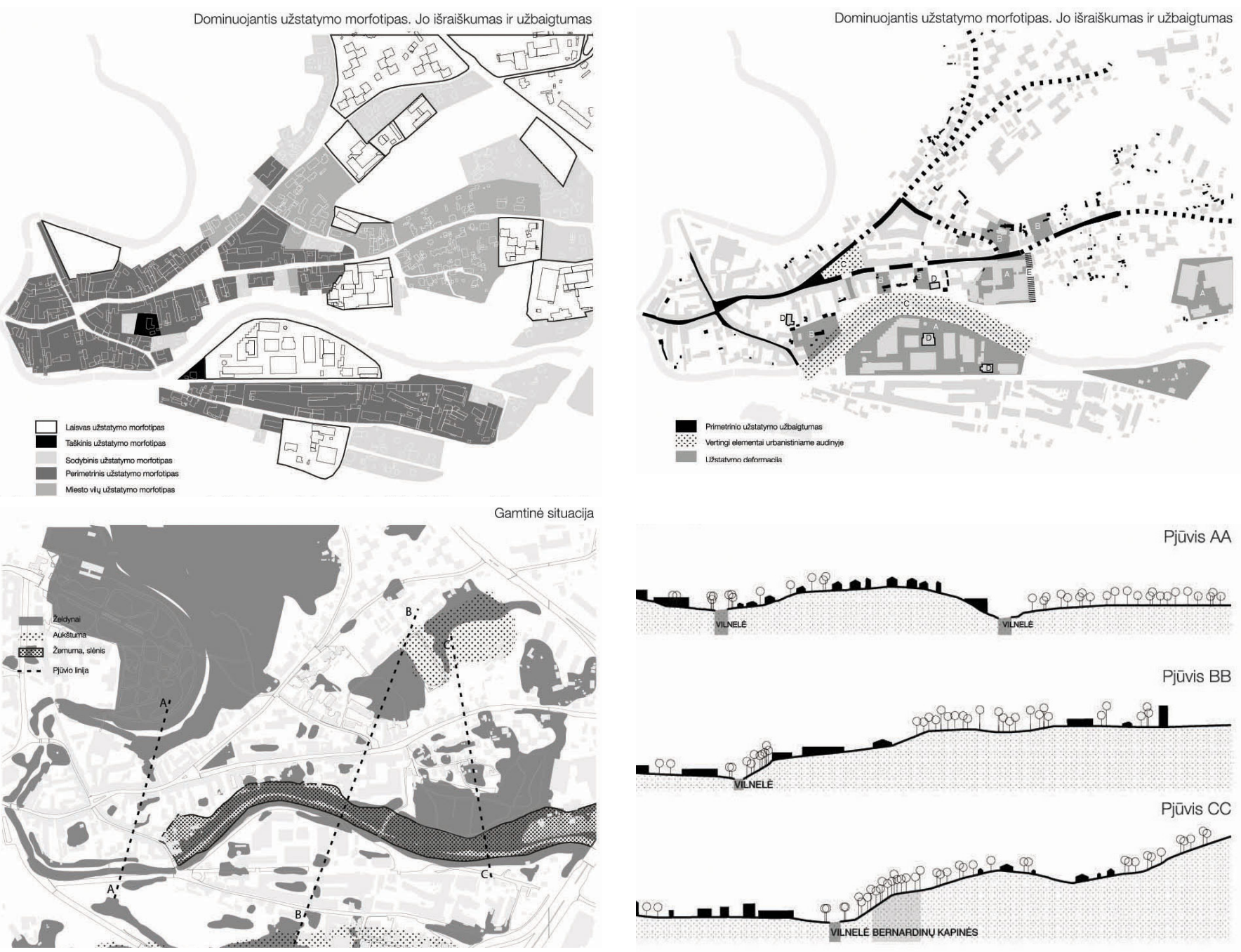

Pjūvis AA

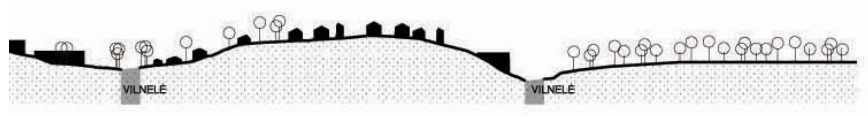

Pjūvis BB
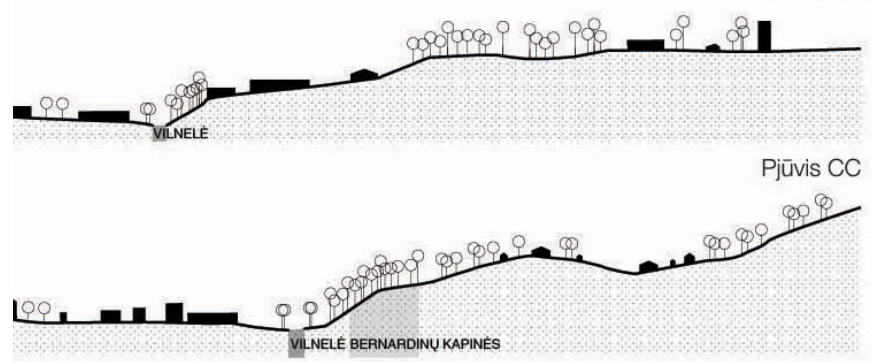

Fig. 1. Analysis (a-d) of urban features of regenerating territory of the part of Vilnius Old Town, Lithuania (student N. Tukaj, tutor D. Dijokiené, 2011).
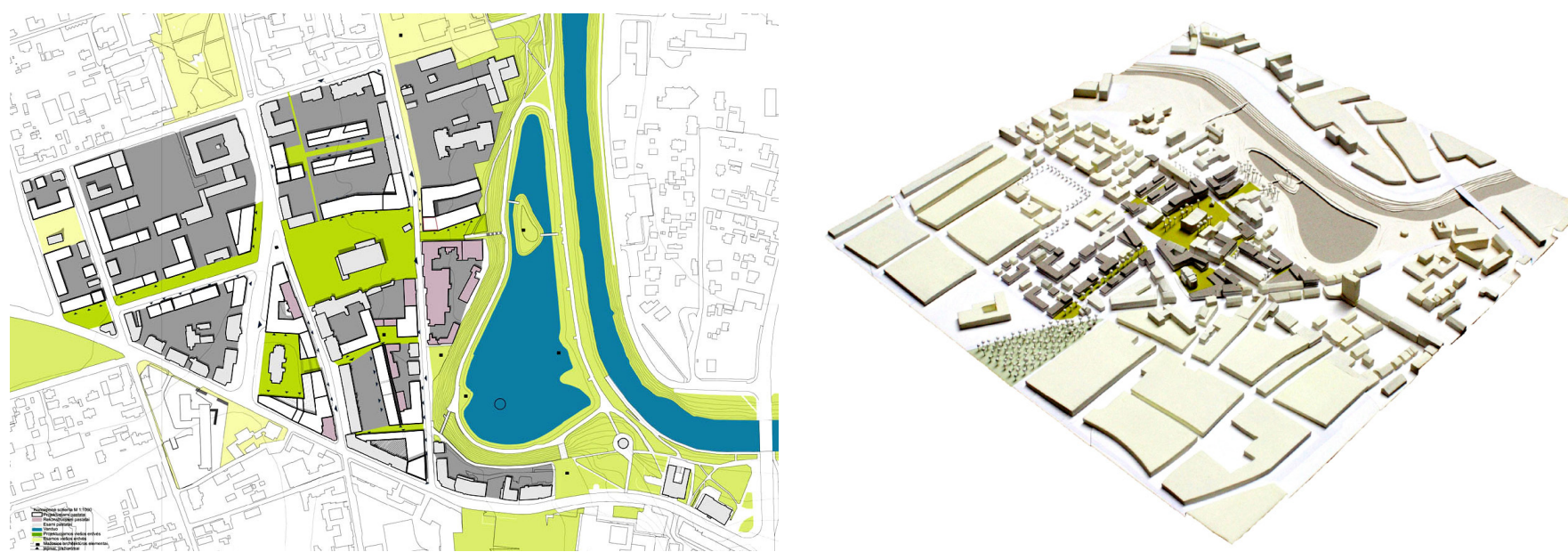

Fig. 2. Drawing (a) and model (b) of concept of regenerating territory of the historical part of Panevėžys, Lithuania (student E. Gumauskaite, tutor D. Dijokienė, 2011).

schemes, plans and a 3-dimentional model. A best reasoned solution is then selected (Figure 2).

Project part. This stage involves the drawing of a detailed plan of the volumetric spatial structure of the selected conceptual solution: the territory's public urban spaces (e.g., squares) and buildings shaping them are presented in detail. In order to make a regenerating block "lively", the plan must include both public and residential buildings (Figure 3). 

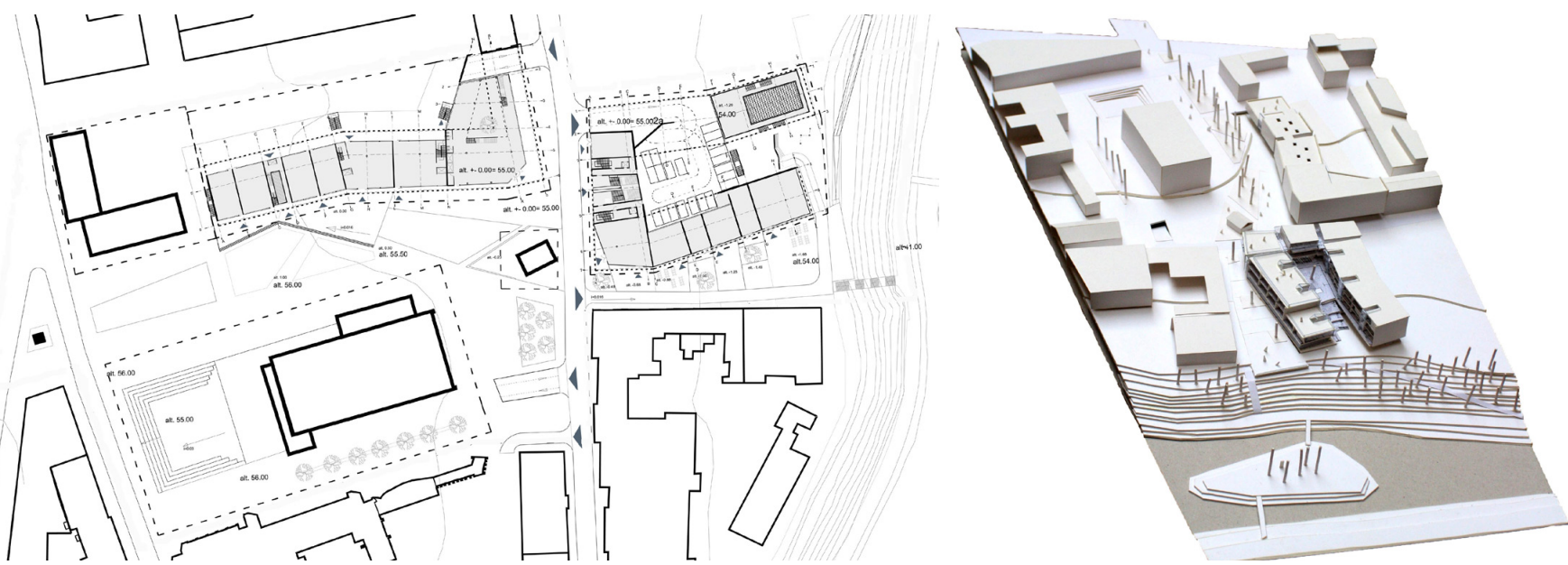

Fig. 3. Blocks of flats in the regenerating territory of the historical part of Panevėžys, Lithuania ( $\mathrm{a}$ - plan of ground floor, $\mathrm{b}-$ model, student E. Gumauskaite, tutor D. Dijokienè, 2011).
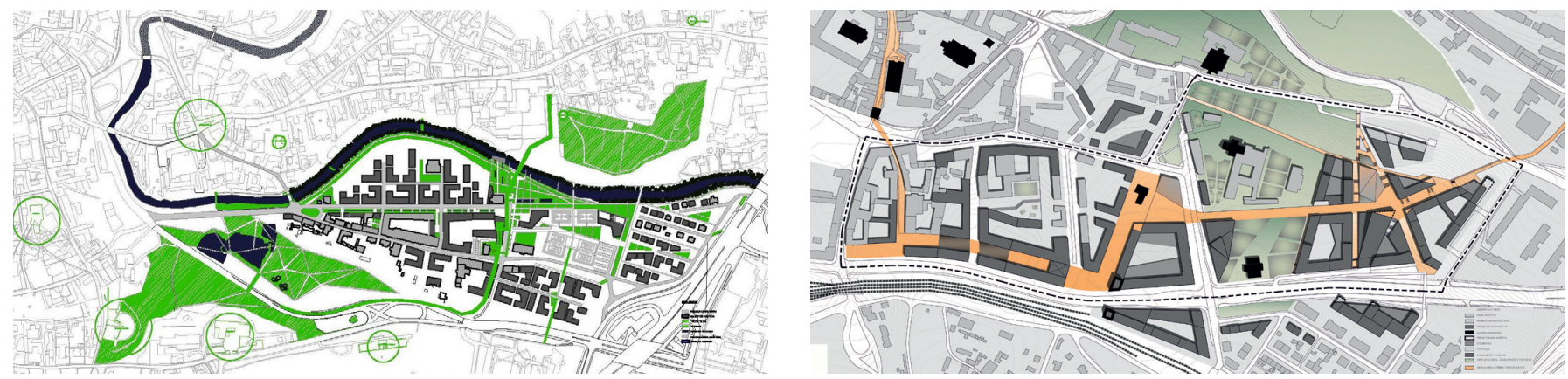

Fig. 4. Principles of plan formation of regenerating territories (a - student E. Archipovaitė, 2007; b - student M. Vaitkutė, 2012, tutor D. Dijokienè).

II. Tasks and Methods of Regeneration of Historical Environment in the Graduation Projects of BA Students

This section of the article looks into the challenges students face when they have to make projects in a historical environment and the principals they base on when creating new urban quality. The urban structure of a town always changes and will be changing in the future - change is the engine of its existence. Each generation makes an effort to preserve in the town everything that it considers valuable and to change everything that seems to need a change. A person with the Western European mentality is more inclined to express, establish and immortalize himself/herself rather than preserve heritage of others. And whether architects take into account the existing urban structure depends on the social aspect of the order that they work on, as well as on the mentality of the architects [4]. If the new urban concept is created ignoring the established structure, it in most cases leads to a conflict and may fail in the end. According to K. Lynch, there is an optimal limit for the signs of the past to stay in existence. If the number of these signs becomes too small, there is a risk of losing orientation. Such radical changes indicate that the "historical clock of the urban structure" is set going once again [5]. Bearing in mind that the historical kernels of towns reflect experience of many generations, which has withstood the test of time, it is essential to preserve the principles of historical built-up and to develop them further by taking into account the established spatial patterns.
Every town has a unique urban structure regardless of whether it has developed spontaneously or in a planned way. The entirety of structural elements (street, square, block, building, etc.) forms a three-dimensional composition of the town - its spatial structure. Students of the Department of Urban Design, FA, VGTU, in their graduation projects seek to maintain contact with the historical environment as well as aim to preserve the valuable features of the urban pattern and to integrate them into the newly developed built-up. New urban quality in a historical environment is designed by plan formation, built-up and volumetric-spatial composition [6].

The review of students' projects reveals the following principles of plan formation in regenerating territories:

- routes of former streets are sought and the attempts to regenerate them are made;

- new links between objects of attraction - cultural heritage objects, public buildings and spaces, etc. - are sought and established;

- public spaces are regenerated and new ones are formed;

- size of blocks is established based on examples from a historical environment (Figure 4).

Future architects who plan new built-up in a historical environment are guided by the following principles:

- preservation of old buildings and their adaptation for new functions (Figure 5a);

- new built-up developed in accordance with the principles 
of traditional architecture (Figure 5b);

- search for new architectural forms (Figures 5c and 5d).

In their attempts to preserve, supplement or create new volumetric-spatial composition of regenerating territories students use the following methods:

- built-up is adjusted to emphatic landscape;

- landscape and water are employed for achieving new quality of public spaces;

- in the formation of built-up, attention is devoted to visual links, to existing valuable dominating elements in the territory;

- new dominating elements are created;

- viewing spots are set up in characteristic viewing locations in the territory (Figure 6).

Sometimes solutions in students' projects are successful, sometimes - less successful. One Lithuanian architect, researcher of the old town's composition, has once said "Success of synthesis of the old and new architecture depends solely on the mastery of the creator" [7]. Synthesis of the old and new architecture is not easily achieved in practice. This is a highly complicated task, somewhat like achieving "synthesis of water and fire". Whichever view we take, renovation projects of the central part of the town, especially the Old Town, should be viewed from the perspective of revitalising cultural memory and strengthening urban communities. The baseline is reinforcement of the structure of historical urban spatial environment, including the existing network of streets and the interaction between volume and appearance of buildings [8].

\section{Conclusions}

International documents published at the turn-of-the-century support the development of historic urban landscapes, which preserves and enforces cultural meaning and special character of the heritage. The most recent documents aim to unify provisions of protection and sustainable usage on the one hand, development and creation of new architecture on the other. They state that architecture should be contextual, contemporary and high-quality. Each new element of architecture should represent its time and the traces of intervention should be recognisable in the future. The international documents released at the beginning of the 21st century treat contemporary architecture as equal to historic one - "historic and contemporary architecture constitute an asset to local communities" [9]. However, simultaneously it should respect the inherited historic context and meet the requirements of integrity and quality.

Architects, urban designers and urban planners represent the segment of the society that is most capable of changing the town's face. Success of their work also depends on perception of the special value of historical environment and the ability to establish a balance between "old and new". The idea that the town's past must be preserved for the sake of its future is not novel but still highly relevant today. The visual aspect of historical environment is among the key factors establishing individual and communal identity. Therefore, projects of renovation of historical environment should be assessed from the perspective of revitalizing the cultural memory and strengthening urban communities. The synthesis of historical environment
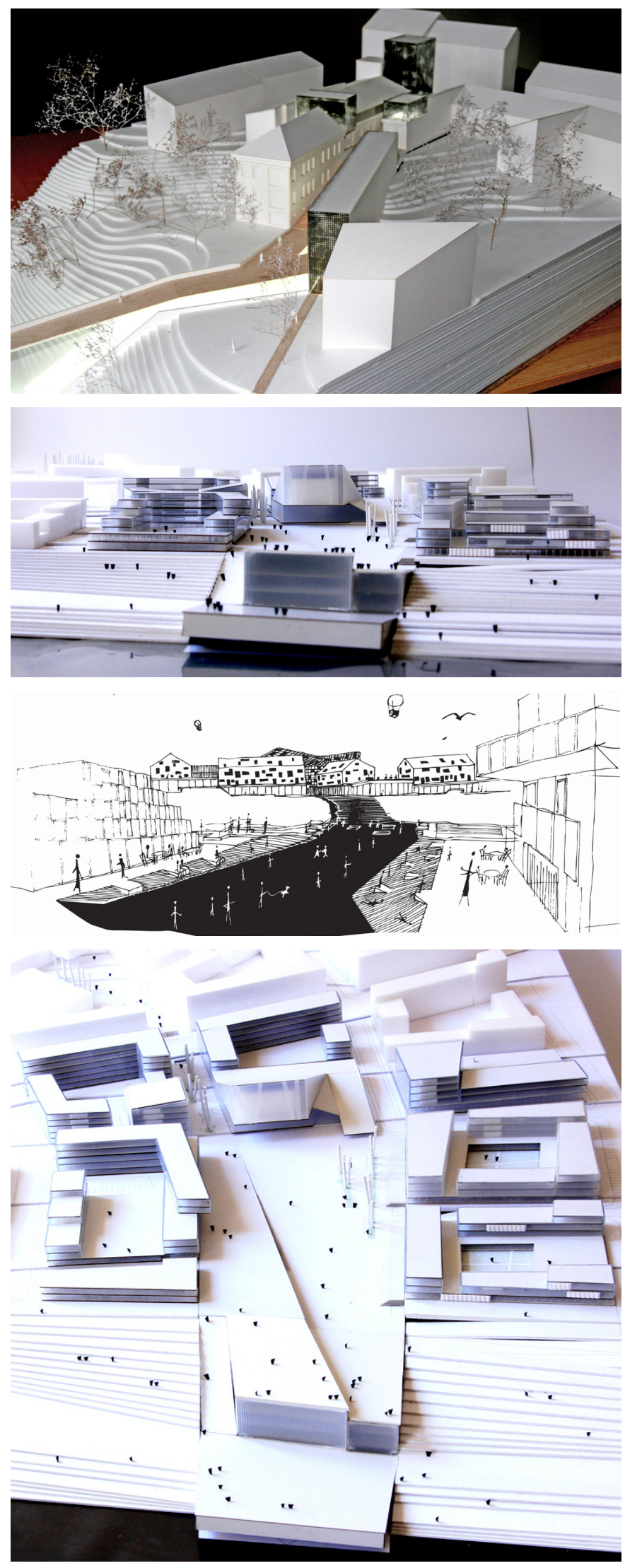

Fig. 5. Principles of build-up formation in regenerating territories (a - student P. Latakas, 2011, tutor T. Grunskis; b - student N. Tukaj, 2011; c-d - student G. Lukšaitè, 2012, tutor D. Dijokienè). 


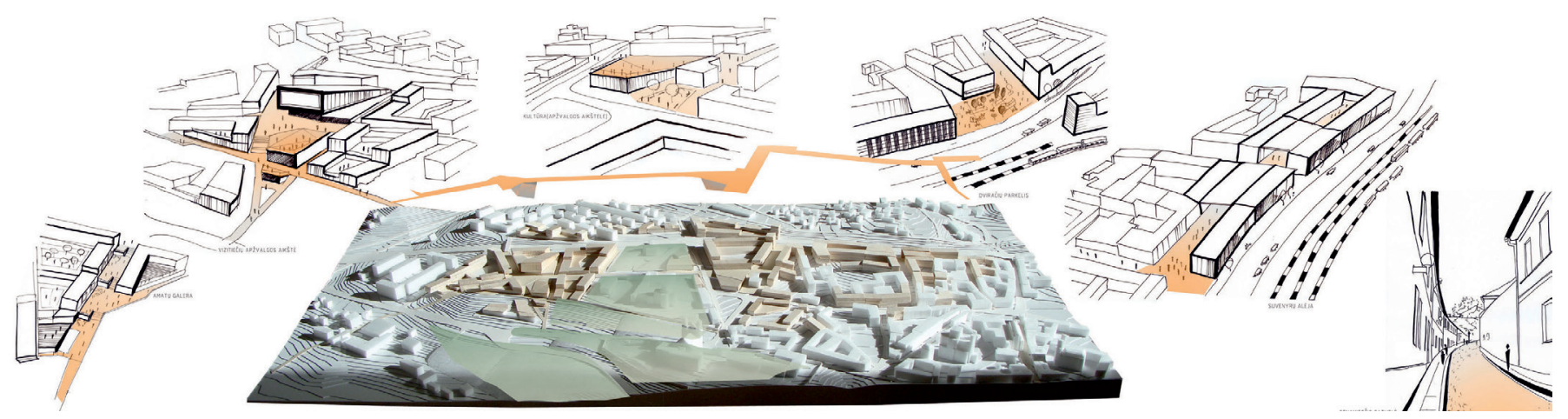

Fig. 6. Principles of formation of volumetric-spatial composition of regenerating territories (student M. Vaitkute, 2012, tutor D. Dijokienė).

and new structures should maintain a subtle balance among the realization, fostering and utilization of the valuable features of the inherited urban structure, as well as attainment of new quality and development.

On the basis of the projects of the BA students of the Department of Urban Design, FA, VGTU, it may be stated that the young generation of architects is not only interested in the innovative design but also aims to understand and incorporate in their projects the established features of the town's physical form. In their graduation projects, students use consistent methodology and carry out work in the following stages: perform an analysis, form a conceptual system, and prepare a concrete plan. When preparing project proposals, they deal with such tasks as territory's plan formation, integration of new built-up and supplementing of the existing volumetric-spatial composition.

\section{REFERENCES}

1. Rogers, R., Power, A. Mažos valstybès miestai (Cities for a Small Country). Vilnius: Vilniaus dailès akademijos leidykla, 2004. p. 279.

2. Trancik, R. Finding Lost Space. New York, Chichester, Weinheim, Brisbane, Singapore, Toronto: John Wiley \& Sons, 1986. 246 p.

3. Krier, R. Town Spaces : Contemporary Interpretations in Traditional Urbanism. Basel: Birkhäuser, 2006. p. 8-17.

4. Vyšniūnas, A. Miesto gyvenamuju struktūru rekonstrukcija (Reconstruction of Town's Residential Urban Structures). Vilnius: Technika, 2002. 47 p.

5. Линч, К. Образ города. Москва: Стройиздат, 1982. 240 p.

6. Dijokiené, D. Synthesis of Historical Environment and Modern Society. HERITAGE 2012 - Proceedings of the 3rd International Conference on Heritage and Sustainable Development, Barcelos: Green Lines Institute, 2012, Vol. 2, p. 1113-1122. ISBN 978-989-95671-5-3.

7. Jurkštas, V. Vilniaus senamiesčio tūrinè-erdviné kompozicija (Volumetricspatial Composition of Vilnius Old Town). Architektūros paminklai, Vol. 4, 1977, p. 36-120.

8. Rubavičius, V. Vilniaus senamiestis - gyvosios kultūrinès atminties šerdis (Vilnius Old Town - Core of Living Cultural Memory). Town Planning and Architecture. Vilnius: Technika, 2011, Vol. 35. No. 4, p. 231-237.

9. Vienna Memorandum on World Heritage and Contemporary Architecture - Managing the Historic Urban Landscape [online]. UNESCO World Heritage Centre [cited 08.09.2011]. http://whc.unesco.org/uploads/ activities/documents/activity-48-3.doc

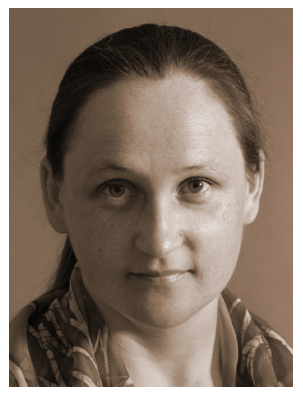

Dalia Dijokienė (Vilnius, 1973). B. arch. (Vilnius Gediminas Technical University, 1995), MSc. arch. (VGTU, 1997), Doctor of Humanities in Architecture (VGTU, 2002). PhD thesis Historical Suburbs: Genesis, Development, Value, Maintenance (on the Example of Lithuanian Towns).

ASSOCIATE PROFESSOR at the Department of Urban Design, Faculty of Architecture, Vilnius Gediminas Technical University (VGTU, since 2004); Guest Lecturer at the University of Florence, Italy (2006), University of Turin, Italy (2006), Cracow University of Technology, Poland (2012). ARCHITECT-TRAINEE (Lyngby, Denmark, 1999), ARCHITECT (Closed Joint Stock Company “Atkirta UAB”, 1998-2007), private ARCHITECT (since 2007). She is the author and co-author of more than 30 architectural projects. She has delivered reports at 7 international $(2000,2002$, 2007, 2008, 2010, 2012 (2)), 7 national conferences (1999, 2000, 2001(2), 2002, 2008, 2011). She is the author of 18 scientific publications: 7 of them are published in the national scientific journal "Town Planning and Architecture" (2000, 2001, 2006(2), 2009, 2011 (2)), others papers - in the journals of international scientific publications $(2000,2002,2007,2009,2010,2012(3))$; summary of doctoral dissertation (2002); monograph (2009).

Recent research publications:

- Dijokienè, D. Synthesis of Historical Environment and Modern Society. HERITAGE 2012 - Proceedings of the 3rd International Conference on Heritage and Sustainable Development, Barcelos: Green Lines Institute, 2012, Vol. 2, p. 1113-1122. ISBN 978-989-95671-5-3.

- Dijokiené, D. Urbanistikos paveldo tvarkybos ištakos ir šiandieninè situacija Lietuvoje [Origins and Present Situation of Management of Urban Heritage in Lithuania], Urbanistika ir architektūra = Town Planning and Architecture, Vilnius: Technika, 2011, Vol. 35. No 4, p. 238-248. ISSN 1392-1630 [in Lithuanian].

- Dijokienė, D. Urbanistinis istoriniu priemiesčiu paveldas. Urban Heritage of Historical Suburbs. Vilnius: Technika, 2009. 216 p. ISBN 978-9955-28-473-4.

Current and previous research interests: urban nuances of the town spatial expansion beyond the old town's borders, urban design and history of town spatial development.

She is a Member of the Second Immovable Cultural Heritage Assessment Board (Department of Cultural Heritage under the Ministry of Culture), specialization in the Council - architectural and urban immovable cultural heritage (since 2010).

\section{Contact Data}

Dalia Dijokienè

Vilnius Gediminas Technical University, Faculty of Architecture, Department of Urban Design

Address: Pylimo 26/1, Vilnius 01132, Lithuania

Phone: +370 65067897

E-mail: dalia.dijokiene@ vgtu.lt, ddijokiene@gmail.com 